\title{
A New Approach for the Synthesis of 3-Substituted Cytotoxic Nor- $\beta$-Lapachones
}

\author{
Mariana F. C. Cardoso, ${ }^{a, b}$ Illana M. C. B. da Silva, ${ }^{a}$ Helvécio M. dos Santos Júnior, \\ David R. Rocha, ${ }^{a}$ Ana Jérsia Araújo, ${ }^{d}$ Claudia Pessoa, ${ }^{d}$ Manoel O. de Moraes, ${ }^{d}$ \\ Letícia V. C. Lotufo, ${ }^{d}$ Fernando de C. da Silva, ${ }^{a}$ Wilson C. Santos ${ }^{b}$ and Vitor F. Ferreira ${ }^{*, a}$ \\ ${ }^{a}$ Departamento de Química Orgânica, Instituto de Química, \\ Universidade Federal Fluminense, 24020-141 Niterói-RJ, Brazil \\ ${ }^{b}$ Departamento de Farmácia e Administração Farmacêutica, Faculdade de Farmácia, \\ Universidade Federal Fluminense, 24241-000 Niterói-RJ, Brazil \\ 'Departamento de Química Orgânica, Instituto de Química, Cidade Universitária, \\ Universidade Federal do Rio de Janeiro, 21944-970 Rio de Janeiro-RJ, Brazil \\ ${ }^{d}$ Departamento de Fisiologia e Farmacologia, Faculdade de Medicina, \\ Universidade Federal do Ceará, 60430-270 Fortaleza-CE, Brazil
}

\begin{abstract}
Vários estudos têm mostrado o potencial citotóxico de derivados da nor- $\beta$-lapachona contra células tumorais. Considerando a nor- $\beta$-lapachona um importante protótipo, uma série inédita de nor- $\beta$-lapachonas substituídas em C-3 foi sintetizada através de uma nova metodologia sintética envolvendo intermediário sintético 3-hidróxi-nor- $\beta$-lapachona para o acoplamento de alguns nucleófilos contendo núcleos derivados de carboidratos ou $2 \mathrm{H}$-pirazóis. Todos os derivados foram avaliados frente a quatro linhagens de células tumorais. Duas das substâncias apresentaram moderada citotoxicidade, enquanto as demais inibiram fortemente todas as linhagens tumorais testadas.
\end{abstract}

Several studies have demonstrated the cytotoxic potential of nor- $\beta$-lapachone derivative against cancer cells. Considering nor- $\beta$-lapachone as an important prototype, a set of new 3 -substituted nor- $\beta$-lapachones was synthesized by a new synthetic route that involves the use of synthetic intermediate generated for coupling with several nucleophiles containing the carbohydrate and $2 \mathrm{H}$-pyrazole substituent moieties. All the compounds were screened against four tumor cell lines. Two of the compounds showed moderate cytotoxicity, while the other compounds strongly inhibit all tested cancer cell lines.

Keywords: naphthoquinone, heterocycle, cytotoxicity, carbohydrate

\section{Introduction}

Cancer is a leading cause of death worldwide and accounted for 7.6 million deaths (around 13\% of all deaths) in 2008. ${ }^{1}$ The development of new chemotherapeutic agents for the treatment of cancer is urgently needed and the search for new natural or synthetic substances that display this activity remains a challenge to medical science. Drugs containing a quinone moiety, such as anthracyclines, mitoxantrones and lapachol, show excellent anticancer activity. ${ }^{2}$ Among these, it is highlighted the naphthoquinones, which possess a diverse range of

*e-mail: cegvito@vm.uff.br biological activities, justifying the numerous studies in the literature on the synthesis and evaluation of either natural quinones or their analogues as potential antitumor agents. ${ }^{3-7}$

Despite the broad spectrum of biological activities of the naphthoquinones, their mechanism of action is not well understood. Some studies have indicated that the mechanism involves the nuclear enzymes topoisomerases I and II, ${ }^{8,9}$ and other studies have shown that the quinones can be reduced by one or two electrons, resulting in intermediates that can induce a redox cycle and generate reactive oxygen species (ROS), thereby inducing apoptosis. ${ }^{10}$

Figure 1 shows a group of natural and synthetic naphthoquinones, of which lapachol (1) is the most well-known member. Lapachol is present as a constituent 
of various plant families, including the Bignoniaceae, Leguminosae, Sapotaceae, Scrophulariaceae, Verbenaceae, Malvaceae and Proteaceae. Lapachol exhibits an impressive list of important biological activities ${ }^{11}$ such as trypanocidal, ${ }^{12}$ antimalarial, antitubercular, ${ }^{13}$ antitumor, ${ }^{14}$ antibacterial ${ }^{15}$ and antileishmanial, ${ }^{16}$ as well as activity against the snail Biomphalaria glabrata ${ }^{17}$ (which is involved in the transmission of schistosomiasis)..$^{18}$ The structure of lapachol was the inspiration for other important analogues, such as atovaquone (2) and buparvaquone (3), both are important 3-substituted-2-hydroxy-1,4-naphthoquinones used as drugs for the treatment of Pneumocystis pneumonia, toxoplasmosis and malaria (Figure 1). The multiple and varied antimicrobial activity of lapachol and structurally related compounds highlights the importance of this class of compounds (Figure 1). An important derivative of lapachol (1) is the $\beta$-lapachone (4), an ortho-naphthoquinone naturally obtained from a native South America tree Tabebuia avellanedae with a wide range of pharmacological activities, including anti-bacterial, antifungal, anti-trypanosomal, anti-retroviral and anti-inflammatory activities ${ }^{19-26}$

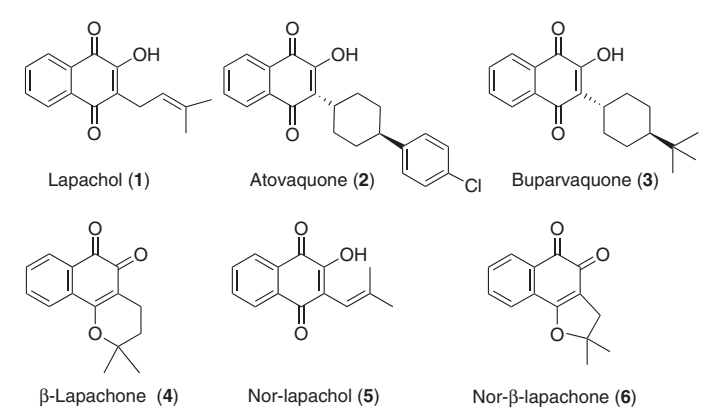

Figure 1. Examples of important natural and synthetic naphthoquinones.

Another compound, nor-lapachol (5), is a synthetic derivative that can be obtained from $\mathbf{1}$ by a degradation reaction with $\mathrm{H}_{2} \mathrm{O}_{2}$, known as the Hooker reaction, ${ }^{27}$ or by the condensation of 2-hydroxy-1,4-naphthoquinone with isobutyraldehyde..$^{28}$ Compound $\mathbf{5}$ can be cyclized in a strong acid, producing nor- $\beta$-lapachone (6). Recently, it was reported that $\mathbf{6}$ induced a weak in vitro cytotoxic activity in non-tumor cells (human cultured lymphocytes and Chinese hamster lung fibroblasts) showing some selectivity for tumor cells. The cytotoxic effect is related to the compound ability to decrease the intracellular level of the enzyme glutathione S-transferase (GSH), leading to an even greater pro-oxidant condition in cells. ${ }^{29}$ The elevated oxidative activity in the cells creates an antiproliferative environment. Compound $\mathbf{5}$ was investigated as a starting material in the synthesis of new substances that would demonstrate better anticancer and trypanocidal activity. In this respect, it is highlighted substances $\mathbf{9}$ and $\mathbf{1 0}$, which were more active against cancer cells and Trypanosoma cruzi, respectively (Scheme 1).

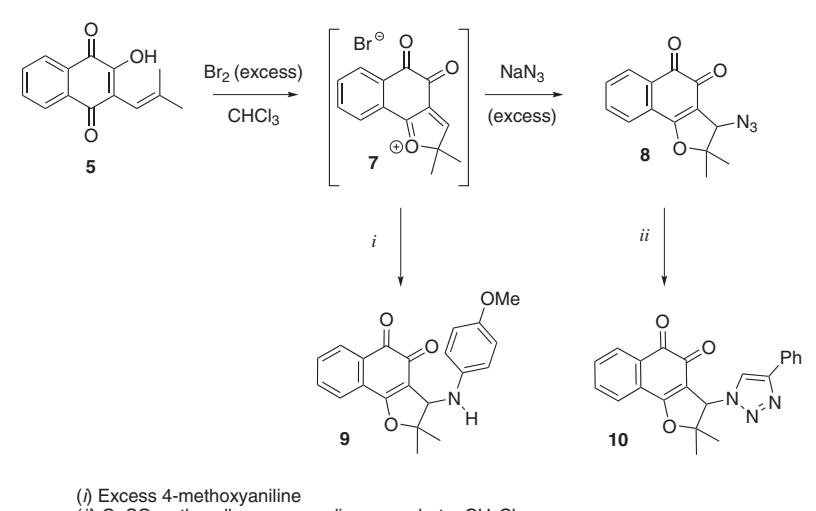

(i) Excess 4-methoxyaniline

Scheme 1. Transformation of $\mathbf{5}$ into naphthoquinones $\mathbf{9}$ and $\mathbf{1 0}$.
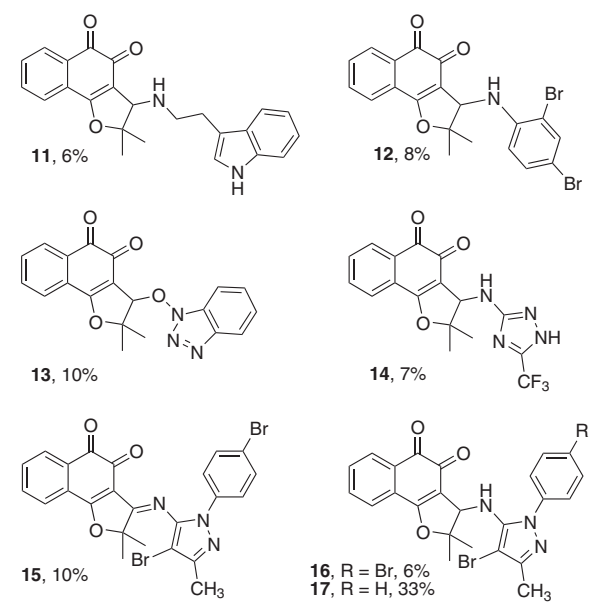

Figure 2. Naphthoquinones 11-17 obtained with conditions of Scheme 1.

As can be seen in Scheme 1, the methodology used to prepare the derivatives of $\mathbf{6}$ substituted in the pyran ring employed the $2 H$-naphtho-[1,2-b]-furanylium ion generated in situ by bromine. However, this protocol has several disadvantages, and cannot be used as a general method. The large excess of bromine and nucleophiles (over 50 equiv.) limit their use. ${ }^{3,5}$ The excess bromine itself can react with the nucleophiles, generating undesirable brominated products and/or degradation of the nucleophile due to high oxidizing power of bromine. In addition, bromine is toxic and hazardous to human health. Furthermore, its high vapor pressure makes it difficult to be easily manipulated.

Continuing with our interest in the synthesis of 3 -substituted nor- $\beta$-lapachones, our group describes in this work the synthesis of various 3 -substituted nor- $\beta$-lapachones coupled with heterocyclic pyrazole and carbohydrate derivatives and its cytotoxic potential against four cancer cell lines. 


\section{Results and Discussion}

\section{Chemistry}

The nor- $\beta$-lapachone compounds were synthesized using an alternative methodology that utilizes the nucleophiles in stoichiometric amounts, without the formation of byproducts like those from the reaction of bromine and nucleophiles.

Initially, some test reactions were performed under the same conditions that were previously reported by our group. ${ }^{3,5}$ Using tryptamine, aniline, benzotriazol-1-ol and 5-trifluoromethyl-1H-[1,2,4]-triazol-3-ylamine, the furan-naphthoquinones 11, 12, 13 and 14, respectively, were obtained in low yield. When 5-methyl-2-phenyl$2 \mathrm{H}$-pyrazol-3-ylamine was used, the reaction produced the compounds 15 and 16 or 17. During these reactions, the excess bromine reacted with heterocyclic and aromatic rings. Several reactions were also attempted with acetonides of carbohydrates, but none of them isolated the desired glycoconjugates due to extensive decomposition of the carbohydrates under this condition.

To resolve the challenge of bromine reactivity in this reaction, it was changed the synthetic route (Scheme 2). First, the compound 5 was converted into 3-hydroxynor- $\beta$-lapachone (18), ${ }^{30}$ which was converted under mild conditions in the same $2 H$-naphtho[1,2-b]furanylium intermediate ion (7). The compound (7) reacted with various nucleophiles, producing the nor- $\beta$-lapachone $(\mathbf{1 9 a}-\mathbf{h})$. With this synthetic route, it was possible to isolate the pyrazole-naphthoquinones (19a-e) and the glycoconjugates (19f-h) with moderate yields and recover the reagent (18).

\section{Biological assay}

Several studies have demonstrated the potential cytotoxic of nor- $\beta$-lapachone derivatives against cancer cells. ${ }^{3-6,31}$ The in vitro anticancer activity of new nor- $\beta$-lapachone derivatives (15-17 and 19a-h) was assessed against four human cancer cell lines, OVCAR-8 (ovarian), HCT-116 (colorectal), SF-295 (central nervous system) and HL-60 (leukaemia), in comparison to doxorubicin, the positive control, by using MTT (yellow dye 3-(4,5-dimethyl2-thiazolyl)-2,5-diphenyl-2 $\mathrm{H}$-tetrazoliumbromide) assay. ${ }^{31}$ Concentrations that induce 50\% inhibition of cell growth $\left(\mathrm{IC}_{50}\right)$ in $\mu \mathrm{M}$ are reported in Table 1.

Results showed that all compounds are strongly or moderately cytotoxic against all cancer cell lines with $\mathrm{IC}_{50}$ in the range of 0.16 to $32.29 \mu \mathrm{M}$. Based on data collected from two independent experiments, the compound $\mathbf{1 6}$ was considered less active with $\mathrm{IC}_{50}$ values ranging from 11.7 to $32.29 \mu \mathrm{M}$ followed by compound $\mathbf{1 5}$ that showed $\mathrm{IC}_{50}$ values ranging from 3.09 to $22.17 \mu \mathrm{M}$. All other compounds exhibited similar $\mathrm{IC}_{50}$ values ranging from 0.16 to 2.13 (Table 1).

\section{Conclusions}

In summary, this study showed that it is possible to obtain derivatives of nor- $\beta$-lapachone in mild conditions. The results clearly show that the 3-hydroxy-nor- $\beta$-lapachone (18) is a versatile intermediate in the formation of the derivatives (19a-h). In relation to the biological studies, the results presented reaffirm the cytotoxic potential of nor- $\beta$-lapachone derivatives against cancer cell lines.

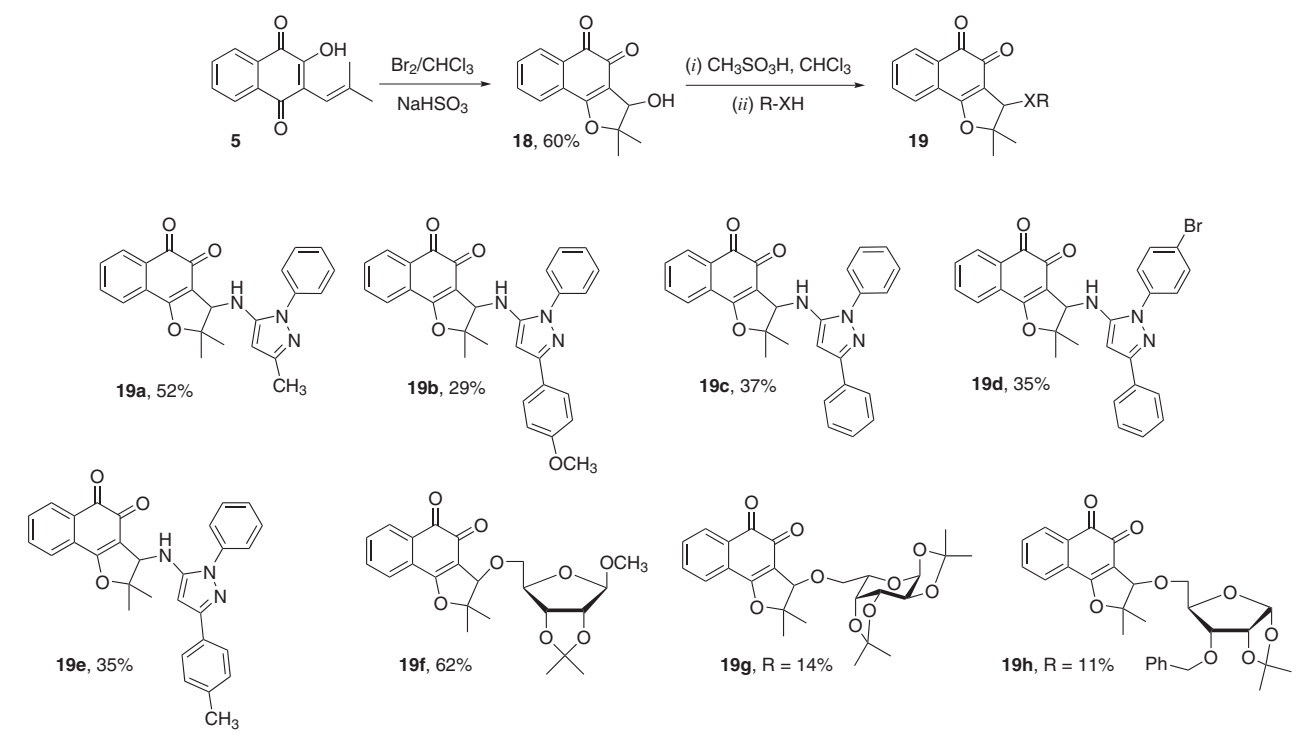

Scheme 2. General scheme used for preparation 3-substituted nor- $\beta$-lapachones. 
Table 1. Cytotoxic activity expressed by $\mathrm{IC}_{50}$ in $\mu \mathrm{M}$ of nor- $\beta$-lapachone derivatives for cancer cell lines, obtained by nonlinear regression for all cell lines from two independent experiments ${ }^{\mathrm{a}}$

\begin{tabular}{lcccc}
\hline Compounds & HL-60 & HCT-116 & SF-295 & OVCAR-8 \\
\hline $\mathbf{1 5}$ & $3.09(2.33-4.09)$ & $8.66(7.41-10.13)$ & $22.17(17.18-28.6)$ & $8.17(7.52-8.86)$ \\
$\mathbf{1 6}$ & $11.7(5.76-23.8)$ & $28.9(23.8-35.1)$ & $27.12(21.95-33.5)$ & $32.29(26.6-39.2)$ \\
$\mathbf{1 7}$ & $0.8(0.65-0.98)$ & $1.59(1.42-1.76)$ & $1.76(0.69-4.5)$ & $1.32(1.13-1.53)$ \\
$\mathbf{1 9 a}$ & $0.73(0.58-0.93)$ & $1.15(1.0-1.3)$ & $2.13 \mathrm{nd}$ & $1.05(0.93-1.15)$ \\
$\mathbf{1 9 b}$ & $0.57(0.53-0.63)$ & $1.87(1.75-1.97)$ & $1.71(1.59-1.83)$ & $1.24(1.08-1.44)$ \\
$\mathbf{1 9 c}$ & $0.43(0.37-0.5)$ & $1.0(0.74-1.32)$ & $1.06(0.98-1.15)$ & $1.08(0.91-1.26)$ \\
$\mathbf{1 9 d}$ & $0.82(0.76-0.89)$ & $1.21(1.11-1.32)$ & $1.04(0.95-1.15)$ & $1.04(0.93-1.15)$ \\
$\mathbf{1 9 e}$ & $0.34(0.29-0.42)$ & $0.72(0.61-0.82)$ & $1.05(1.01-1.12)$ & $0.99(0.74-1.33)$ \\
$\mathbf{1 9 f}$ & $0.35(0.3-0.4)$ & $0.63(0.58-0.67)$ & $0.33(0.28-0.35)$ & $0.88(0.84-0.93)$ \\
$\mathbf{1 9 g}$ & $0.23(0.21-0.27)$ & $0.35(0.31-0.37)$ & $0.23(0.21-0.27)$ & $0.70(0.64-0.74)$ \\
$\mathbf{1 9 h}$ & $0.16(0.14-0.18)$ & $0.51(0.47-0.55)$ & $0.34(0.32-0.36)$ & $0.89(0.83-0.93)$ \\
Doxorubicin & $0.03(0.02-0.03)$ & $0.21(0.15-0.29)$ & $0.41(0.34-0.46)$ & $0.45(0.29-0.52)$ \\
\hline
\end{tabular}

${ }^{\mathrm{a} D a t a}$ are presented as $\mathrm{IC}_{50}$ values in $\mu \mathrm{M}$ with and $95 \%$ confidence intervals obtained by nonlinear regression for all cell lines from two independent experiments. Doxorubicin was used as positive control. nd: not determined.

\section{Supplementary Information}

Experimental details and supplementary data are available free of charge at http://jbcs.sbq.org.br as PDF file.

\section{Acknowledgments}

The authors would like to thank the CNPq (National Council for Technological and Scientific Development), CAPES (Brazilian Federal Agency for Support and Evaluation of Graduate Education) and Fundação de Amparo à Pesquisa do Estado do Rio de Janeiro (FAPERJPRONEX, E-26/171.512.2010) for funding this work. V. F. F. and W. C. S. are members of the INCT-REDOXOMA.

\section{References}

1. http://www.who.int/mediacentre/events/annual/world_cancer_ day/en/index.html accessed in September 2012.

2. Sengupta, S. K. In Cancer Chemotherapeutic Agents; Foye, W. O., ed.; American Chemical Society: Washington-D.C., 1995, pp. 205-239.

3. Júnior, E. N. S; de Souza, M. C. B. V.; Pinto, A. V.; Pinto, M. C. F. R.; Goulart, M. O. F.; Barros, F. W. A.; Pessoa, C.; Costa-Lotufo, L. V.; Montenegro, R. C.; de Moraes, M. O.; Ferreira, V. F.; Bioorg. Med. Chem. 2007, 15, 7035.

4. Júnior, E. N. S; Moura, M. A. B. F.; Pinto, A. V.; Pinto, M. C. F. R.; de Souza, M. C. B. V.; Araújo, A. J.; Pessoa, C.; Costa-Lotufo, L. V.; Montenegro, R. C.; Moraes, M. O.; Ferreira, V. F.; Goulart, M. O. F.; J. Braz. Chem. Soc. 2009, $20,635$.

5. Júnior, E. N. S.; de Deus, C. F.; Martins, J. B. L.; Lima, A. B.; Cavalcanti, B. C.; Pessoa, C.; Costa-Lotufo, L. V.; Montenegro,
R. C.; Moraes, M. O.; Pinto, M. C. F. R.; de Simone, C. A.; Ferreira, V. F.; Goulart, M. O. F.; Andrade, K. Z.; Pinto, A. V. J. Med. Chem. 2010, 53, 504.

6. Araújo, A. J.; de Souza A. A.; Júnior, E. N. S.; Marinho-Filho, J. D. B.; de Moura, M. A. B. F.; Rocha D. D.; Vasconcellos, M. C.; Costa, C. O.; Pessoa, C.; Moraes, M. O.; Ferreira, V. F.; de Abreu, F. C.; Pinto, A. V.; Montenegro, R. C.; Costa-Lotufo, L. V.; Goulart, M. O. F.; Toxicol. in Vitro 2012, 26, 585.

7. Montenegro, R. C.; Araújo, A. J.; Molina, M. T.; Marinho-Filho, J. D. B.; Rocha, D. D.; Lopéz-Montero, E.; Goulart, M. O. F.; Bento, E. S.; Alves, A. P. N. N.; Pessoa, C.; Chem.-Biol. Interact. 2010, 184, 439.

8. Boothman, D. A.; Trask, D. K.; Pardee, A. B.; Cancer Res. 1989, 49, 605.

9. Anderson, R. D.; Berger, N. A.; Mutation Res. 1994, 309, 109.

10. Monksm T. J.; Jones, D. C.; Curr. Drug Metab. 2002, 3, 425; Park, E. J.; Choi, K. S.; Kwon, T. K.; Chem.-Biol. Interact. 2011, 189, 37; Lien, Y. C.; Kung, H. N.; Lu, K. S.; Jeng, C. J.; Chau, Y. P.; Histol. Histopathol. 2008, 23, 1299.

11. Castellanos, J. R. G.; Prieto, J. M.; Heinrich, M.; J. Ethnopharmacol. 2009, 121, 1.

12. Ferreira, V. F.; Jorqueira, A.; Souza, A. M. T.; da Silva, M. N.; de Souza, M. C. B. V.; Gouvêa, R. M.; Rodrigues, C. R.; Pinto, A. V.; Castro, H. C.; Santos, D. O.; Araújo, H. P.; Bourguignon, S. C.; Bioorg. Med. Chem. 2006, 14, 5459; Jorqueira, A.; Gouvêa, R. M.; Ferreira, V. F.; da Silva, M. N.; de Souza, M. C. B. V.; Zuma, A. A.; Cavalcanti, D. F. B.; Araújo, H. P.; Bourguignon, S. C.; Parasitol. Res. 2006, 99, 429; Silva-Jr., E. N.; Menna-Barreto, R. F. S.; Pinto, M. C. F. R.; Silva, R. S. F.; Teixeira, D. V.; de Souza, M. C. B. V.; Simone, C. A.; de Castro, S. L.; Ferreira, V. F.; Pinto, A. V.; Eur. J. Med. Chem. 2008, 43, 1774; Ferreira, S. B.; Salomão, K.; da Silva, F. C.; Pinto, A. V.; 
Kaiser, C. R.; Pinto, A. C.; Ferreira, V. F.; de Castro, S. L.; Eur. J. Med. Chem. 2011, 46, 3071; Bourguignon, S. C.; Cavalcanti, D. F.; de Souza, A. M. T.; Castro, H. C.; Rodrigues, C. R.; Albuquerque, M. G.; Santos, D. O.; da Silva, G. G.; da Silva, F. C.; Ferreira, V. F.; Experimental Parasitol. 2011, 127, 160; Bourguignon, S. C; Castro, H. C.; Santos, D. O.; Alves, C. R.; Ferreira, V. F.; Seguis, W. S.; Gama, I. L.; da Silva, F. C.; Pinho, R. T.; Experimental Parasitol. 2009, 122, 91.

13. Ferreira, S. B.; da Silva, F. C.; Bezerra, F. A. F. M.; Lourenço, M. C. S.; Kaiser, C. R.; Pinto, A. C.; Ferreira, V. F.; Arch. Pharm. 2010, 343, 81 .

14. Francisco, A. I.; Vargas, M. D.; Fragoso, T. P.; Carneiro, J. W. M.; Casellato, A.; da Silva, F. C.; Ferreira, V. F.; Pessoa, C.; Costa-Lotufo, L. V.; Marinho-Filho, J. D. B.; Moraes, M. O.; Mangrich, A. S.; J. Braz. Chem. Soc. 2010, 21, 1293; Eyong, K. O.; Kumar, P. S.; Kuete, V.; Folefoc, G. N.; Nkengfack, E. A.; Baskaranm, S.; Bioorg. Med. Chem. Lett. 2008, 18, 5387.

15. Freire, C. P. V.; Ferreira, S. B.; de Oliveira, N. S. M.; Matsuura, A. B. J.; Gama, I. L.; da Silva, F. C.; de Souza, M. C. B. V.; Lima, E. S.; Ferreira, V. F.; MedChemComm. 2010, 1, 229; Lourenço, A. L.; Abreu, P. A.; Leal, B.; Silva-Jr., E. N.; Pinto, A. V.; Pinto, M. C. F. R; Pinto, M. C. F. R; Souza, A. M. T.; Novais, J. S.; Paiva, M. B.; Cabral, L. M.; Rodrigues, C. R.; Ferreira, V. F.; Castro, H. C.; Curr. Microbiol. 2011, 62, 684.

16. Teixeira, M. J.; de Almeida, Y. M.; Viana, J. R.; Holanda, J. G.; Rodrigues, T. P.; Prata, J. R. C.; Coelho, I. V. B.; Rao, V. S.; Pompeu, M. M. L.; Phytother. Res. 2001, 15, 44; da Silva, A. J. M.; Netto, C. D.; Pacienza-Lima, W.; Torres-Santos, E. C.; Rossi-Bergmann, B.; Maurel, S.; Valentind, A.; Costa, P. R. R.; J. Braz. Chem. Soc. 2009, 20, 176; Lima, N. M. F.; Correia, C. S.; Leon, L. L.; Machado, G. M. C.; Madeira, M. F.; Santana, A. E. G.; Goulart, M. O. F.; Mem. Inst. Oswaldo Cruz 2004, 99, 757.

17. Silva, T. M. S.; Câmara, C. A.; Barbosa, T. P.; Soares, A. Z.; da Cunha, L. C.; Pinto, A. C.; Vargas, M. D.; Bioorg. Med. Chem. 2005, 13, 193; Lima, N. M. F.; Correia, C. S.; Ferraz,
P. A. L.; Pinto, A. V.; Pinto, M. C. R. F.; Santana, A. E. G.; Goulart, M. O. F.; J. Braz. Chem. Soc. 2002, 13, 822.

18. Hussain, H.; Krohn, K.; Ahmad, V. U.; Miana, G. A.; Greend, I. R.; Arkivoc 2007, Part II, 145.

19. Ferreira, S. B.; Gonzaga, D. T. G.; Santos, W. C.; Araújo, K. G. L.; Ferreira, V. F.; Rev. Virtual Quim. 2010, 2, 140.

20. Guiraud, P.; Steiman, R.; Campos Takaki, G. M.; Seigle-Murandi, E.; Simeon, B. M.; Planta Med. 1994, 60, 373.

21. Lopes, J. N.; Cruz, F. S.; Docampo, R.; Vasconcellos, M. E.; Sampaio, M. C.; Pinto, A. V.; Gilbert, B.; Ann. Trop. Med. Parasitol. 1978, 72, 523.

22. Goijman, S. G.; Stoppani, A. O.; Arch. Biochem. Biophys. 1985 , 240, 273.

23. Schuerch, A. R.; Wehrli, W.; Eur. J. Biochem. 1978, 84, 197.

24. Manna, S. K.; Gad, Y. P.; Mukhopadhyay, A.; Aggarwal, B. B.; Biochem. Pharmacol. 1999, 57, 763.

25. Pinto, A. V.; Gilbert, B.; Pinto, M. C.; Ann. Trop. Med. Parasitol. 1978, 72, 523; Corrêa, G.; Vilela, R.; Menna-Barreto, R. F. S.; Midlej, V.; Benchimol, M.; Parasitol. Int. 2009, 58, 424.

26. Ertl, P.; Cooper, D.; Allen, G.; Slater, M. J.; Bioorg. Med. Chem. Lett. 2009, 9, 2863; Crosby, I. T.; Rose, M. L.; Collis, M. P.; de Bruyn, P. J.; Keep, P. L. C.; Robertson, A. D.; Aust. J. Chem. 2008, 61, 768.

27. Hooker, S. C.; J. Am. Chem. Soc. 1936, 58, 1168.

28. Glazunov, V. P.; Berdyshev, D. V.; Yakubovskaya, A. Y.; Pokh, N. D.; Russ. Chem. Bull. Int. Ed. 2006, 55, 1729.

29. Cavalcanti, B. C.; Barros, F. W. A.; Cabral, I. O.; Ferreira, J. R. O.; Magalhães, H. I. F.; Júnior, H. V. N.; Júnior, E. N. S.; de Abreu, F. C.; Costa, C. O.; Goulart, M. O. F.; Moraes, M. O.; Pessoa, C.; Chem. Res. Toxicol. 2011, 24, 1560.

30. Pinto, A. V.; Pinto, M. C. F. R.; de Oliveira, C. G. T.; An. Acad. Bras. Ciênc. 1982, 54, 107.

31. Mosmann, T; J. Immunol. Methods 1983, 65, 55.

Submitted: June 26, 2012

Published online: February 5, 2013 